\title{
Analysis of Potential Alternative Energy Sources for Electricity Conservation in Yogyakarta State Finance Building
}

\author{
Anna Nur Nazilah Chamim ${ }^{* 1}$, Rahmat Adiprasetya Al Hasibi ${ }^{1}$, Agus Jamal ${ }^{1}$, Siva Aprilia ${ }^{1}$, \\ Yessi Jusman ${ }^{1}$, Jeckson ${ }^{2}$ \\ ${ }^{1}$ Department of Electrical Engineering, Universitas Muhammadiyah Yogyakarta \\ J1. Lingkar Selatan, Tamantirto, Kasihan, Yogyakarta, Indonesia \\ ${ }^{2}$ Department of Electrical Engineering, Universitas Muhammadiyah Lampung \\ J1. Zainal Abidin Pagar Alam 14. Lahuban Ratu, Bandar Lampung, Indonesia \\ *Corresponding author, e-mail: anna_nnc@umy.ac.id
}

\begin{abstract}
State Finance Building of Yogyakarta is a community service that is included in the types of buildings that consume considerable electric energy so that often led to the power outage unexpectedly due to excessive use of electricity. This excessive use of electricity has also contributed to bill accounts for electricity from PLN, which each month up to hundreds of millions of dollars. To that end, this research was undertaken that aims to be able to a device that most optimal configuration in the use of solar panels and could compare the SOLAR PV system between On-Grid and PLN in the aspect of cost and $\mathrm{CO}_{2}$ emissions. In knowing the potential of alternative energy sources, namely solar power connected to the PLN as the optimal power plant is carried out employing researching the form of knowing the intensity of the solar radiation data, data in the form of electric power load is active for 24 hours, and data rates time of outside peak load and time of peak load from PLN for State Finance Building Of Yogyakarta. Later, she did the simulation using software to help homer modeling from the use of the most optimal solar panel. The research results obtained that the potential SOLAR PV system that is connected with the grid PLN unfit to be carried out because of the cost of the initial investment to expenses during the period of operation of the system, including the high value of the NPC of \$970,742. However, the potential of the power plant that is appropriate for the conditions on-site research solar power plant was connected to the grid PLN power plant configuration that is optimized for without using batteries, use the only $P V$ with a capacity of $91.35 \mathrm{~kW}$, the converter with a capacity of $400 \mathrm{~kW}$, and power grid network of PLN the system transmitted to SOLAR PV On-Grid of $552 \mathrm{~kW}$.
\end{abstract}

Keywords: State Finance Building of Yogyakarta, SOLAR PV On-Grid, Homer Software, $P L N$

\section{Introduction}

Solar power generation is one alternative energy that has been widely developed, besides other alternative energy such as wind energy, biofuel, tidal energy, and others [1]. Solar cells are made from skinny layers $(0.3-1.0$ micron $)$ of semiconductor material (eg, silicon), glued on glass or flexible plastic [2]. Each cell generally produces a voltage of 0.5 volts; to obtain a higher voltage, individual cells can be connected in series [3]. Almost all solar cell panels apply a 12 volts voltage, thus to get a voltage of 12 volts, 24 cells are needed, but in practice to anticipate compensation for a voltage drop due to many factors [4]. As voltage drop due to losses on the cable, termination, cell efficiency decreases, usually to get a supply voltage of 12 volts requires approximately 28 cells, depending on external factors that can cause "voltage drop." Solar panels must be able to drain a voltage higher than the working voltage of the 
battery; if using a 12 volts battery system, then the solar cell output must be at least 13-14 volts [5].

Yogyakarta State Finance Building (GKN) is a place of community service that is included in the type of commercial buildings that operate or work from morning to evening, thus requiring a large enough supply of electricity. For this reason, the Yogyakarta State Finance Building has one 400 MW generator set and one $1250 \mathrm{kV}$ transformer. Meanwhile, the power connected to PLN is 690,000 $\mathrm{VA}$ and the maximum current is $700 \mathrm{~A}$ and the average use of electricity in the GKN is approximately $575 \mathrm{~A}$.

However, GKN Yogyakarta often experiences blackouts from both PLN and excessive use of electricity. Sometimes, the generator set still cannot back up as a whole when there is a blackout from PLN because the generator also only provides electricity energy reserves for lighting loads and elevators. In addition, the consumption of electricity in the Yogyakarta GKN is considered too excessive or wasteful. Based on the monthly electricity bill, which reaches up to hundreds of millions of rupiah, and the Government raising the electricity bill, so it is considered very burdensome for the GKN Yogyakarta.

As for several previous research reference which is used in some applications. Asya'ari et al (2014) who conduct research on "The Use of Solar Cells with PLN as A Source of Electrical Energy for Homes". The research method used of solar cells with PLN as a source of electrical energy for homes is the measurement of energy that can be supplied by the energy produced from solar cells. In this research, the components are using two solar panels, each with a 100 watt peak capacity, a 12/24 Volt DC controller with a capacity of $60 \mathrm{~A}$, an inverter with a capacity of 500 Watt, accumulator with a capacity of $100 \mathrm{Ah}$, and a Philips DC lamp (5 Watt, 10 Watts, 13 Watts) and 5 SL 18 Watt lamps. After testing, the highest current production is obtained at 12:30 hours, with a current value of 13 A and a voltage of 14 Volt DC. Then, the electricity produced during the day will be used to supply the lighting load, namely lamps at 5PM to 6AM with an average energy that can be used at $1,027 \mathrm{kWh}$ per night [6].

On the other hand, Raharjo et al (2015), research on "Design of Hybrid Solar Cell-Control-BatteryPLN Using Programmable Logic Controllers". This research using a hybrid system from solar cells and from PLN, this use aims to help each other between plants. The components used in this system are using a solar cell with a capacity of 100 wattpeak to produce a voltage of $20.03 \mathrm{~V}$; current $4.52 \mathrm{~A}$; and power of $90.52 \mathrm{~W}$ and experienced a peak load at 1PM. Then, charging the battery is declared to be full or $100 \%$ when the voltage reaches $12.7 \mathrm{~V}$. Whereas, when the battery is in a state of $30 \%$ to $40 \%$ with a voltage of $11.8 \mathrm{~V}$, the battery will be charged again. All systems are controlled with a PLC using the ladder diagram language [7].

The other research by Salman (2013), who research on "Design Analysis of The Use of Solar Power Generation Systems (SOLAR PV) For Housing (Solar Home System)". This research uses a photovoltaic module with a capacity of 50 wattpeak. The average daily solar radiation obtained is $4.5 \mathrm{kWh} / \mathrm{m}^{2}$ which will produce electrical energy of approximately 125 to 130 watt-hours [8].

Therefore, energy conservation efforts are needed to reduce the sudden blackouts caused by the use of excessive electricity and reduce electricity bills to make it more economical by using alternative energy sources in the form of energy from the sun as a source of connected electricity generation with the PLN network. Because of the importance of energy conservation in the Yogyakarta State Finance Building (GKN) so need to be held analysis of alternative source for electrical energy conservation. It is hoped to recommendation for the infrastructure going forward.

\section{Methods}

This research method was conducted to provide a clear picture of the work of this thesis. The writing method is carried out as follows:

\section{II.1. Research Procedure}

Flowchart of research procedure is presented in Fig. 1. Based on the Fig.1, the research carried out includes the following steps:

\section{Data Collection}

The data collection process consists of several data, as follows:

\section{- Load Data}

Data is collected by conducting field surveys directly and carried out using a power quality analyzer. The data taken are loads that are attached to contacts and lighting loads along with the length of load usage and data on current, voltage, frequency, power energy, etc. 24 hours from floor 1 to floor 4 throughout the blocks in Building 1 at GKN Yogyakarta.

- Solar Radiation Potential Data Determination of the potential of solar 
radiation at the research location obtained from NASA through Homer Software that is connected with NASA satellites using the internet. The trick is to look at the resources section of the Homer Software then click solar resource, then enter the coordinates of the location of the research location.

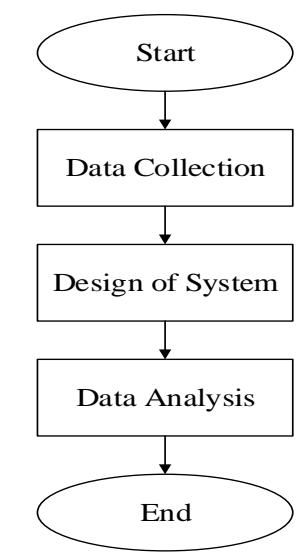

Fig. 1. Flowchart of research procedure

\section{Design of System}

In this research, make design and configuration by inputting input data in the form of solar radiation obtained from the coordinates of the location of the study location, installed electrical loads, and lighting loads at GKN Yogyakarta using the Homer Software. After entering input data, then start designing photovoltaics, batteries, converters, and grids. Next, configure several components, then calculate to get the optimal power plant simulation.

\section{Data Analysis}

From the results of data processing through Homer Software, we will get a result which will then be analyzed as follows:

- Analysis of potential alternative energy sources

- Component configuration analysis

- Electricity and Emission Analysis

- Comparison between SOLAR PV On-Grid with PLN in Terms of Economy

\section{II.2. Research Site and Time}

This research was carried out for approximately two weeks starting on January 16-27 January 2017 with the title "Analysis of The Potential of Alternative Energy Sources for Energy Conservation in The Yogyakarta State Finance Building", located at Jl. Kusumanegara No. 11, Semaki, Umbulharjo, Yogyakarta City, Special Region of Yogyakarta 55166. The maps location is presented by Fig. 2 .

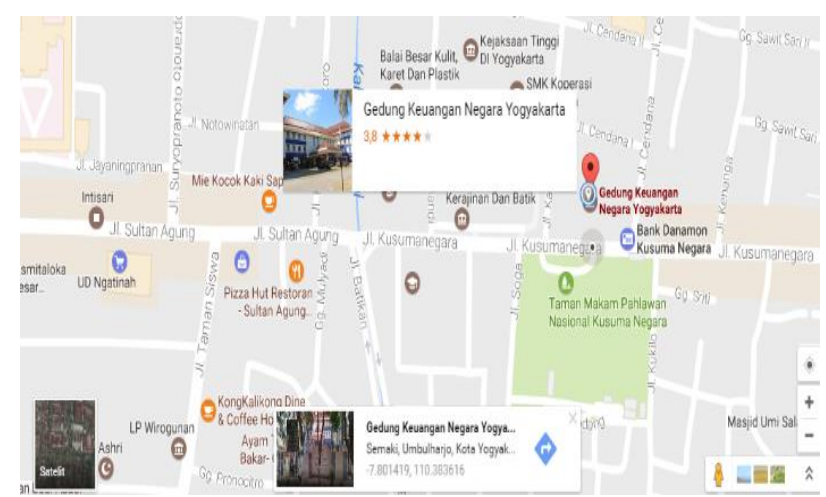

Fig. 2. Location of Yogyakarta State Finance Building

\section{Results}

\section{III.1. Research Data}

1. Electricity Consumption Data Per Day

Electrical energy consumption data recorded by the device are frequency, current and three-phase voltage values, active power values, reactive power values, power factor values, and so on. However, in this research only using the value of active power. Table I is presented for electrical energy consumption.

TABLE I

ELECTRIC ENERGY CONSUMPTION

\begin{tabular}{cc|cc}
\hline \hline Time & Power $(\mathrm{W})$ & Time & Power $(\mathrm{W})$ \\
\hline $00.00-01.00$ & 59404.7 & $12.00-13.00$ & 152558.5 \\
$01.00-02.00$ & 59522.4 & $13.00-14.00$ & 161764.8 \\
$02.00-03.00$ & 58946.9 & $14.00-15.00$ & 174047.2 \\
$03.00-04.00$ & 59019.8 & $15.00-16.00$ & 184424.4 \\
$04.00-05.00$ & 58574.4 & $\mathbf{1 6 . 0 0 - 1 7 . 0 0}$ & $\mathbf{1 8 8 7 2 0 . 9}$ \\
$05.00-06.00$ & 49617.5 & $17.00-18.00$ & 130603.1 \\
$06.00-07.00$ & 111378 & $18.00-19.00$ & 103170.2 \\
$07.00-08.00$ & 171542 & $19.00-20.00$ & 78944.7 \\
$08.00-09.00$ & 184116.4 & $20.00-21.00$ & 62663.4 \\
$\mathbf{0 9 . 0 0 - 1 0 . 0 0}$ & $\mathbf{1 8 8 8 3 5}$ & $21.00-22.00$ & 59037.2 \\
$10.00-11.00$ & 52738.7 & $22.00-23.00$ & 49361.7 \\
$11: 00-12.00$ & 187370.3 & $23.00-00.00$ & 59693.3 \\
\hline \multicolumn{4}{l}{}
\end{tabular}

From the table of electrical energy consumption it can be concluded that the peak load occurs as much as 2 times a day, which is around 9AM to $10 \mathrm{AM}$ are effective hours for starting work for example load of electrical equipment such as computers began to be used intensively and other equipment loads and lighting loads. Then, the second peak load is from 4PM to 5PM because the hours are carried out to do work again after recess. That is because the rest hour provided at GKN Yogyakarta is around 13.30 until 15.00 , the peak of 
work activities using the load of electrical equipment is at $16.00-17.00$, even though 17.00 is the end of work at GKN Yogyakarta.

\section{Potential of Solar Energy}

Solar radiation data on Homer Software simulation requires a year of data to be able to make an On-Grid SOLAR PV. The data needed by the Homer Software to perform optimization or configuration on the SOLAR PV On-Grid system is the Clearness Index data and daily radiation $\left(\mathrm{kWh} / \mathrm{m}^{2} / \mathrm{d}\right)$ for one year. From the data potential of solar energy for the research location that will be built on the SOLAR PV On-Grid system that is obtained an average Clearness Index of 0.483 and an average radiation per day of 0.483 and the average radiation per day is $4.8 \mathrm{kWh} / \mathrm{m}^{2} / \mathrm{d}$. Here is a Table II is presented of solar radiation data obtained from Homer Software.

TABLE II

LifeTime CALCUlation DATA PER Year

\begin{tabular}{ccc}
\hline \hline Month & Clearness Index & Daily Radiation \\
\hline January & 0.396 & 4.28 \\
February & 0.413 & 4.47 \\
March & 0.437 & 4.59 \\
April & 0.484 & 4.72 \\
May & 0.533 & 4.73 \\
Juni & 0.542 & 4.55 \\
July & 0.559 & 4.80 \\
August & 0.563 & 5.25 \\
September & 0.545 & 5.54 \\
October & 0.506 & 5.39 \\
November & 0.438 & 4.71 \\
December & 0.426 & 4.57 \\
\hline \hline
\end{tabular}

\section{III.2. Design of SOLAR PV}

The design of this On-Grid SOLAR PV system is the design of a solar power system that connects with the PLN grid network using Homer Software where the Homer Software is used for modeling on renewable energy by considering the load requirements and available energy sources and to simulate energy operations that provide energy calculations balanced in a year. Homer Software is also capable of modeling optimal small-scale generating systems and system evaluation in OffGrid and On-Grid conditions. The design of SOLAR PV is carried out as follows.

\section{Component Selection}

To design the SOLAR PV On-Grid system itself uses several components, namely primary load 1 , photovoltaic (PV), converter, battery, and this system is connected to the Grid.
2. Determination of the Potential of Solar Energy

In determining the potential of solar energy, it is done by using Homer Software, namely solar resource click, then enter the latitude and longitude values of the research location and select the time zone that is part of Indonesia. Then, click Get Data via the Internet to get the value of clearness index, daily radiation, and a graph of the potential of solar energy for one year obtained through NASA satellites that are connected with Homer Software. Fig. 3. show of how to determine the potential of solar energy.

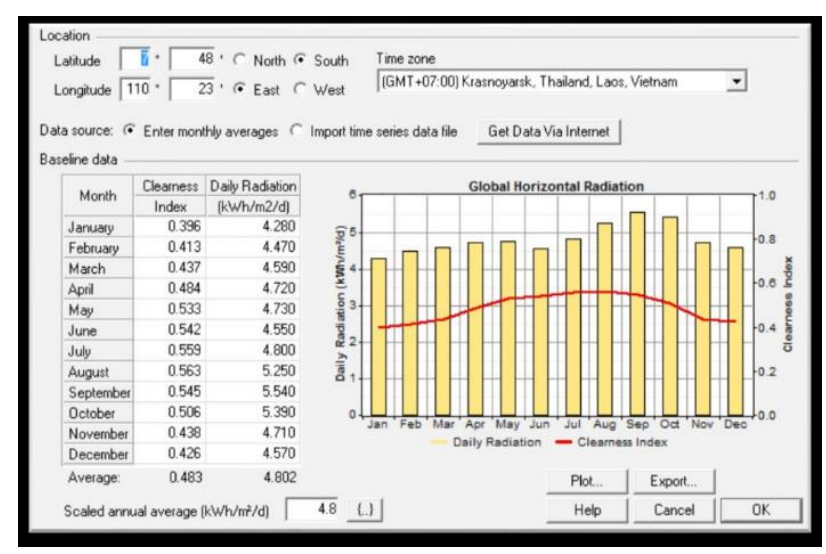

Fig. 3. How to determine the potential of solar energy

\section{Load Data Entry}

Daily random variability used in the generating system is assumed to be $15 \%$ with a time to step of $20 \%$ according to the homer energy instructions. Fig 4 show designing primary loads in Homer Software.

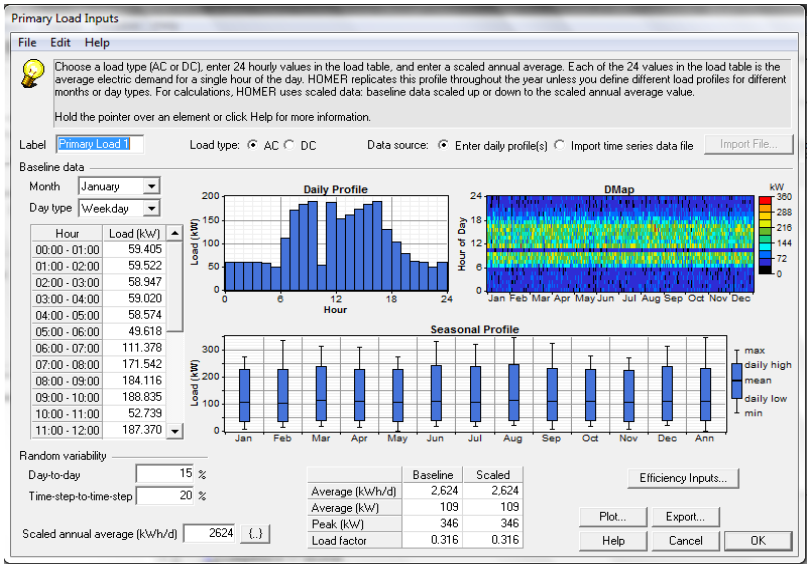

Fig. 4. Designing primary loads in Homer Software

Based on the simulation results shown in the Fig.4, the average electrical energy used per day is 2.6 MWh / d, the average electricity load is 109 $\mathrm{kW}$, and the peak load that is likely to occur is 346 $\mathrm{kW}$ annually. Thus, the load factor which is the 
ratio between the average electricity load and peak load is 0.316 .

\section{Design of photovoltaic (PV)}

In placing the PV on the roof of this building, you must first know the area of the roof of the building facing north. However, it is necessary to first know the area per solar panel which is then multiplied by the number of solar panels needed in this system. The following equations:

$$
\begin{aligned}
\text { Area per solar panel } & =\text { length } \times \text { width } \\
& =1956 \mathrm{~mm} \times 992 \mathrm{~mm} \\
& =1940352 \mathrm{~mm}^{2}=1,94 \mathrm{~m}^{2}
\end{aligned}
$$

Total area of solar panels

$=$ area per solar panel $\times$ total number of solar panels

$$
=1.94 \mathrm{~m} 2 \times 261 \text { pieces }
$$

$=506.34 \mathrm{~m}^{2}$

\section{Design of Battery}

In battery design the first thing to do is to choose the type of battery in the battery type section. After that, fill in the three inputs, namely cost, size to consider/string, and batteries per string. Meanwhile, costs are the same as photovoltaic design which is divided into three parts, namely capital, replacement, and O\&M.

Then, in this simulation the batteries per string totaled 19 batteries because the voltage of the battery itself is $2 \mathrm{~V}$, so that to equalize the voltage required by the solar system at $38 \mathrm{~V}$ it requires 19 batteries.

\section{Design of Converter}

In the design of the converter there are three inputs that must be filled in the same way as the design of photovoltaic namely size $(\mathrm{kW})$, cost, and size to consider. Costs are divided into three parts namely: capital, replacement, and O\&M.

Replacement costs are considered to be the same as capital costs because if there is a total damage to these components, then the damage must be replaced as a whole. Meanwhile, costs of O\&M are assumed to be non-existent because the converter has no maintenance. Then for the size to consider section can be designed according to the most optimal configuration chosen by the Homer Software and in this simulation the most optimal converter capacity is $400 \mathrm{~kW}$.

\section{Design of Grid}

In designing this system using a connection to the grid that aims if there is an excess of electrical energy, then the electrical energy can be sold to PLN. Another goal is to assist as a supplier of electricity if PV cannot supply electricity due to cloudy or rainy weather. Then, in designing this grid, there are three settings that are carried out, including:

- Setting of rates

- Setting of emition $\left(\mathrm{CO}_{2}\right)$

- Setting of advance

\section{III.3. Analysis of Simulation}

Based on the simulation using Homer Software. From 20 times simulation and 8 times sensitivies, there is he lowest NPC value when without battery and only uses photovoltaics, converter, and

\begin{tabular}{|c|c|c|c|c|c|c|c|c|c|}
\hline 1甲回 & $\begin{array}{c}\mathrm{PV} \\
(\mathrm{kW})\end{array}$ & $\mathrm{H} 3000$ & $\begin{array}{l}\text { Conv. } \\
(\mathrm{kW})\end{array}$ & $\begin{array}{l}\text { Gind } \\
(\mathrm{kW})\end{array}$ & $\begin{array}{c}\text { Initial } \\
\text { Capital }\end{array}$ & $\begin{array}{l}\text { Operating } \\
\text { Cost }(\$ / y r)\end{array}$ & $\begin{array}{l}\text { Total } \\
\text { NPC }\end{array}$ & $\begin{array}{c}\mathrm{COE} \\
(\mathrm{S} / \mathrm{kWh})\end{array}$ & $\begin{array}{l}\text { Ren. } \\
\text { Frac. }\end{array}$ \\
\hline 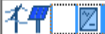 & 91.35 & & 400 & 552 & $\$ 56.756$ & 71.498 & $\$ 970,742$ & 0.079 & 0.13 \\
\hline & & & & 552 & so & 79,694 & $\$ 1,018,752$ & 0.083 & 0.00 \\
\hline & 91.35 & 95 & 400 & 552 & $\$ 263,001$ & 81,974 & $\$ 1,310,909$ & 0.107 & 0.13 \\
\hline 国 & & 95 & 400 & 552 & $\$ 211,845$ & 91,061 & $\$ 1,375,913$ & 0.112 & 0.00 \\
\hline & 91.35 & 190 & 400 & 552 & $\$ 469,246$ & 92,451 & $\$ 1,651,075$ & 0.135 & 0.13 \\
\hline 国 & & 190 & 400 & 552 & $\$ 418,090$ & 101,537 & $\$ 1,716,080$ & 0.140 & 0.00 \\
\hline 国 & 91.35 & 285 & 400 & 552 & $\$ 675,491$ & 102,927 & $\$ 1,991,242$ & 0.163 & 0.13 \\
\hline 图图 & & 285 & 400 & 552 & $\$ 624,335$ & 112,014 & $\$ 2,056,246$ & 0.168 & 0.00 \\
\hline 因图 & 91.35 & 380 & 400 & 552 & $\$ 881,736$ & 113,403 & $\$ 2,331,408$ & 0.190 & 0.13 \\
\hline 1 图 & & 380 & 400 & 552 & $\$ 830,580$ & 122,490 & $\$ 2,396,413$ & 0.196 & 0.00 \\
\hline
\end{tabular}
connected to the grid network. Fig. 5 show of the results of simulation configuration using Homer Software.

Fig. 5. The results of the simulation configuration using Homer Software

Based on Fig. 5. Here, the configuration data optimal if using SOLAR PV On-Grid system, there are:

1. PV

PV that is used is with a capacity of $91.35 \mathrm{~kW}$ with 261 pieces of $\mathrm{PV}$ needed

2. Converter

The converter used is a capacity of $400 \mathrm{~kW}$ with the number of converters needed as many as 8 pieces.

3. Grid

The power connected from the grid is $552 \mathrm{~kW}$.

4. Renewable Fraction

This Renewable Fraction is worth 0.13 , which indicates that this system which is sourced from solar energy only supplies as much electrical energy only $13 \%$ and $87 \%$ are supplied by PLN because the system is connected to the PLN grid. 


\section{III.4. Analysis of Electricity}

Result of analysis electricity using Homer Software shown on Fig. 6.

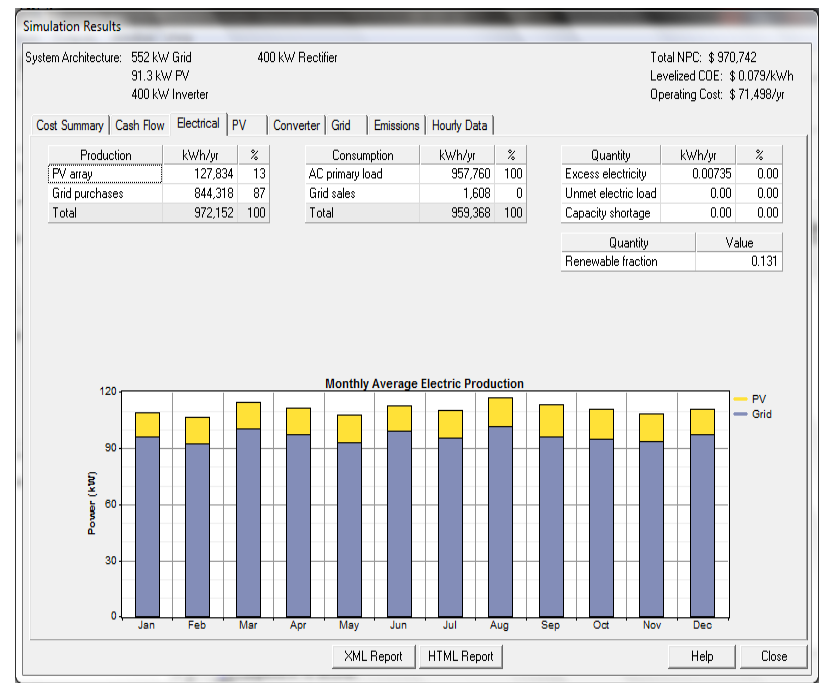

Fig. 6. The results of the generation of the On-Grid SOLAR PV system

From the results of simulations using Homer Software the electrical data obtained are divided into 3 parts, there is:

1. Production of electricity energy

Electrical energy generated by solar energy using photovoltaics for 1 year is $127,834 \mathrm{kWh}$ or $13 \%$ of the total electricity production by the entire power plant. Then, the average PV output power is $350 \mathrm{kWh} / \mathrm{sec}$, and the maximum output power is $89.2 \mathrm{kWh}$, and the operating hours in a year are 4,383 hours. Meanwhile, the electricity produced by PLN is $844,318 \mathrm{kWh}$ per year or $87 \%$ of the total production.

2. Electricity consumption

Yogyakarta State Finance Building is 957,760 $\mathrm{kWh}$ per year or as much as $100 \%$ of the total electricity consumption because in this system the largest electricity production is produced by PLN, hence the value of grid sales is very small at $1,608 \mathrm{kWh} /$ year or at all the electricity production produced by PV arrays are unable to sell electricity to PLN because electricity production from $\mathrm{PV}$ arrays is relatively small, not reaching $50 \%$, even only $13 \%$.

3. Excess electrical energy

The excess electrical energy in the On-Grid SOLAR PV system is very small at $0.00735 \mathrm{kWh}$ per year or at $0 \%$ which is the same as the absence of excess electrical energy because the electrical energy generated by the PV array is only a little $13 \%$ of the total production.
Then, for the capacity of the inverter after simulation, the most optimal capacity used in this system is $400 \mathrm{~kW}$. The most optimal capacity of this converter that will be used to convert electrical energy generated from PV arrays is $127,834 \mathrm{kWh}$ per year. Following are the simulation results from the converter by Table III.

TABLE III

INVERTER SIMULATION RESULTS

\begin{tabular}{ccc}
\hline \hline Quantity & Inverter & Unit \\
\hline Capacity & 400 & $\mathrm{~kW}$ \\
Average of Out & 13 & $\mathrm{~kW}$ \\
Minimal Output & 0 & $\mathrm{~kW}$ \\
Maksimal Output & 80 & $\mathrm{~kW}$ \\
Capacity Factor & 3.3 & $\%$ \\
Operational Time & 4,383 & $\mathrm{hrs} / \mathrm{yr}$ \\
Incoming Energy & 127,834 & $\mathrm{kWh} / \mathrm{yr}$ \\
Energy Comes Out & 115,050 & $\mathrm{kWh} / \mathrm{yr}$ \\
Power Losses & 12,784 & $\mathrm{kWh} / \mathrm{yr}$ \\
\hline \hline
\end{tabular}

\section{III.5. Analysis of Emissions $\mathrm{CO}_{2}$}

After conducting an analysis in terms of electricity, then subsequently analyzing in terms of $\mathrm{CO}_{2}$ emissions. The value of $\mathrm{CO}_{2}$ emissions from this system is $719,674 \mathrm{~kg}$ per year. That is because the SOLAR PV system is connected to the PLN grid, therefore there is a value of $\mathrm{CO}_{2}$ emissions even though this system uses solar energy that is environmentally friendly and does not cause pollution as a source of power generation. The results of emissions is presented by Fig. 7 .

\begin{tabular}{|l|r|}
\hline \multicolumn{1}{|c|}{ Pollutant } & Emissions $(\mathrm{kg} / \mathrm{yr})$ \\
\hline Carbon dioxide & 719,674 \\
\hline Carbon monoxide & 0 \\
\hline Unburno............ & 0 \\
\hline Particulate matter & 0 \\
\hline Sulfur dioxide & 2,309 \\
\hline Nitrogen oxides & 1,129 \\
\hline
\end{tabular}

Fig. 7. $\mathrm{CO}_{2}$ emissions from the On-Grid SOLAR PV system

\section{III.6. Comparison between SOLAR PV On-Grid System and Pure PLN in Economic Sectors}

Based on the Electricity Tariffs Per kWh of the most optimal On-Grid SOLAR PV system is $\$ 0.079$ or Rp. $1.060,-$. However, electricity sold to PLN is very small at $1,608 \mathrm{kWh}$ per year due to electricity production. So, to get surplus to PLN get by following this calculation:

$$
\begin{aligned}
\text { Cost of sales to PLN } & =\text { grid sales } \times \text { sold cost } \\
& =1.068 \mathrm{kWh} / \text { year } \mathrm{x} \$ 0,25
\end{aligned}
$$




$$
=\$ 402 / \text { year }
$$

Purchase costs from PLN

$$
\begin{aligned}
& =\text { grid purchased } \times \text { power tariff } \\
& =844.318 \mathrm{kWh} / \text { year } \times \$ 0,083 / \mathrm{kWh} \\
& =\$ 70.078 / \text { year }
\end{aligned}
$$

$$
\begin{aligned}
\text { Surplus } & =\text { cost of sales }- \text { purchase cost } \\
& =\$ 402-\$ 70.078 \\
& =\$-69.676 / \text { year }
\end{aligned}
$$

From the calculation above, we get a surplus or net profit for one year of $\$-69,676$. This indicates that the On-Grid SOLAR PV system has no advantage because the cost of selling electricity to PLN is smaller than the cost of purchasing electricity from PLN and it is clear that this system does not have a payback period.

However, if the On-Grid SOLAR PV system is compared with PLN, the On-Grid SOLAR PV system will get a payback period. The following is comparison data between the On-Grid SOLAR PV and PLN systems by Fig. 8 .

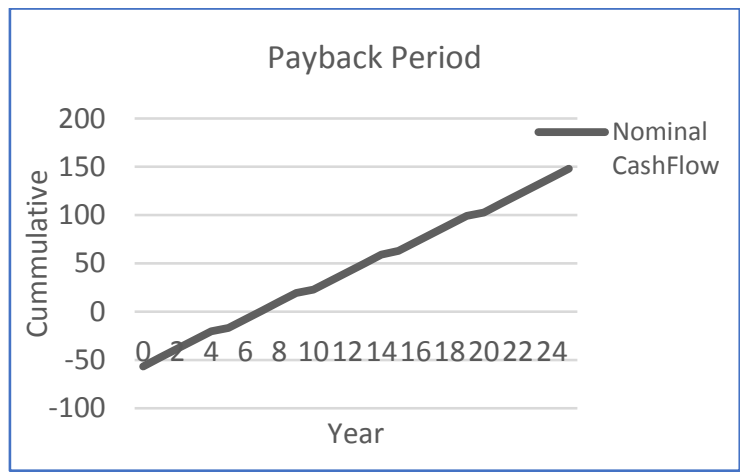

Fig. 8. Graphic of result payback period

Based on Fig. 8, the value of the difference between this system and PLN results in a payback period for this On-Grid SOLAR PV system, which starts to benefit in the 6.86 year rounded up in the 7 th year. However, as much as this project is not feasible to be carried out and if it continues to be implemented it will get a loss because it has an NPC value greater than 0 , even though the project will benefit if it has an NPC value of less than 0 .

\section{Conclusion}

From the results of the research data, the configuration of several components used in this On-Grid SOLAR PV system, and simulations using Homer Software can be concluded as follows:

1. The best and optimal configuration in this
SOLAR PV system is to use a photovoltaic with a capacity of $91.35 \mathrm{~kW}$ with a total of $261 \mathrm{PV}$ modules, a converter with a capacity of $400 \mathrm{~kW}$ with a total of 8 units, and PLN grid network power supplied to this On-Grid SOLAR PV system of $552 \mathrm{~kW}$, and renewable fraction in this system of 0.13 .

2. The result of electricity in this On-Grid SOLAR PV system is that electricity production gets contribution from PV arrays by $13 \%$ and PLN by $87 \%$ which produces total electrical energy of $972,152 \mathrm{kWh} /$ year. Then, the burden served is $957,760 \mathrm{kWh} /$ year. And the results of $\mathrm{CO}_{2}$ emissions released in this system during the operating period each year amounted to 719,674 $\mathrm{kg}$.

3. Economic results in the On-Grid SOLAR PV system obtained the total cost of expenditure from the beginning of construction until during the operation period of $\$ 970,742$ with an electric power rate per $\mathrm{kWh}$ of $\$ 0.079$. Then, this system does not benefit because the annual profit is $\$$ 69,676, but after a comparison with PLN the payback period starts in the 7 th year.

\section{Acknowledgements}

This work was supported by Universitas Muhammadiyah Yogyakarta.

\section{References}

[1] Y. Chen et al., "Investigation of Correlation between Field Performance and Indoor Acceleration Measurements of Potential Induced Degradation (PID) for c-Si PV Modules", 33rd Eur. Photovolt. Solar Energy Conf. Exhibition, pp. 1408-1413, Nov. 2017.

[2] W. Luo et al., "In-situ characterization of potentialinduced degradation in crystalline silicon photovoltaic modules through dark I-V measurements", IEEE J. Photovolt., vol. 7, no. 1, pp. 104-109, Jan. 2017.

[3] C. Corrado et al., "Power generation study of luminescent solar concentrator greenhouse", J. Renew. Sustain. Energy, vol. 8, no. 4, 2016.

[4] C. Corrado et al., "Optimization of gain and energy conversion efficiency using front-facing photovoltaic cell luminescent solar concentrator design", Sol. Energy Mater. Sol. Cells, vol. 111, pp. 74-81, 2013.

[5] M. G. Debije, V. A. Rajkumar, "Direct versus indirect illumination of a prototype luminescent solar concentrator", Sol. Energy, vol. 122, pp. 334340, 2015. 
[6] H. Asy'ari, A. Rozaq, and F. S. Putra, "Pemanfaatan Solar Cell dengan PLN Sebagai Sumber Energi Listrik Rumah Tinggal," Skripsi, Universitas Muhammadiyah Surakarta, Surakarta, 2014.

[7] P. Raharjo, B. Sujanarko, and T. Hardianto, "Perancangan Sistem Hibrid Solar Cell-Baterai-PLN Menggunakan Programmable Logic Controllers," Berkala Saintek, vol. 3(1), pp. 1-5, 2015.

[8] R. Salman, "Analisis Perencanaan Penggunaan Sistem Pembangkit Listrik Tenaga Surya (SOLAR PV) Untuk Perumahan (Solar Home System," Majalah Ilmiah Bina Teknik, vol. 1(1), pp. 46-51, 2013.

\section{Authors' information}

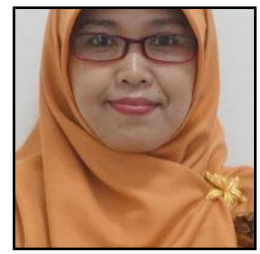

Anna Nur Nazilah Chamim obtained her B.Eng. in Electrical Engineering from Universitas Muhammadiyah Yogyakarta, Indonesia. Her Master study was done at 2015 at the Electrical Engineering, Universitas Gadjah Mada, Indonesia. She currently is a lecture in department of electrical engineering, Universitas Muhammadiyah Yogyakarta.

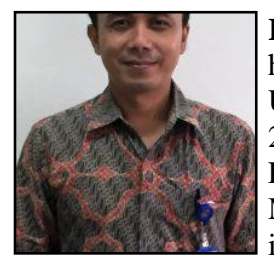

Rahmat Adiprasetya Al Hasibi obtained his B.Eng. in Electrical Engineering from Universitas Gadjah Mada, Indonesia in 2001. His Master study was done at the Electrical Engineering, Universitas Gadjah Mada, Indonesia. He currently is a lecture in department of electrical engineering, Universitas Muhammadiyah Yogyakarta.

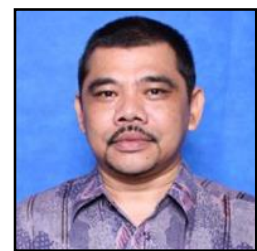

Agus Jamal obtained his B.Eng. in Electrical Engineering from Universitas Gadjah Mada, Indonesia in 1994. His Master study was done at 2010 at the Electrical Engineering, Universitas Gadjah Mada, Indonesia. He currently is a lecture in department of electrical engineering, Universitas Muhammadiyah Yogyakarta.

Siva Aprilia obtained his B.Eng. in Electrical Engineering from Universitas Muhammadiyah Yogyakarta, Indonesia in 2017.

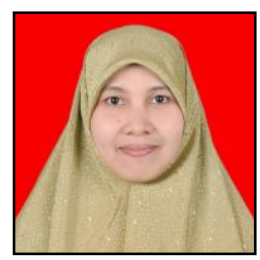

Yessi Jusman obtained her B.Eng. in Electrical and Electronic Engineering from Andalas University, Indonesia in 2007. She worked as a Research Assistant started in July 2008 until November 2009 in Universiti Sains Malaysia. Her Master study was done at 2012 at the School of Electrical and Electronic Engineering, USM Engineering Campus in Nibong Tebal, Penang, Malaysia. She was finished her Ph.D. degree at 2016 in University of Malaya with specializes in Image, Signal Processing, and algorithms. She currently is a lecture in Department of Electrical Engineering, Universitas Muhammadiyah Yogyakarta.

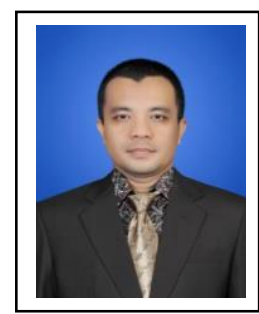

Jeckson obtained his B.Eng. in Electrical Engineering from Universitas Muhammadiyah Yogyakarta, Indonesia, in 1999. His Master study was done at 2015 at the Electrical Engineering, Universitas Negeri Padang, Indonesia. He currently is a lecture in department of Electrical Engineering, Universitas Muhammadiyah Lampung. His main research interest is in power sistem analysis, energy conversion, power electronics, and power system protection. 